\title{
Formalizing Land Rights: Liability of the Indonesian Land Agency for the Loss of Vital Archives
}

\author{
Toar Neman Palilingan* Donna Okthalia Setiabudhi Toar K.R. Palilingan \\ Faculty of Law, Sam Ratulangi University, North Sulawesi, Indonesia
}

\begin{abstract}
The research aims to determine the role of vital archives for registration of land rights in realizing legal certainty for freehold over land and the form of liability of the National Land Agency for loss of vital archives. The research was a socio-legal research using a descriptive method. To analyze the data, the researcher processes and analyzes qualitatively. The results show that the vital archive for land registration has a very important role in the legal certainty of land rights. It is a data record of land registration that connects the land owner with his/her land. In addition, vital archive is an evidence of the truth of the procedure for the issuance of land certificates as well as an evidence of the correctness of land ownership by right holders. The form of liabilities of the National Land Agency for the loss of vital archive for land registration is administrative, civil and criminal liabilities. But unfortunately, this has not been regulated in the legislation in the agrarian sector. Until now, the application of these liabilities can be done based on the archive's laws.
\end{abstract}

Keywords: Land; Land Right; Vital Archive

DOI: $10.7176 / \mathrm{JLPG} / 89-21$

Publication date:September $30^{\text {th }} 2019$

\section{Introduction}

Land rights have been growing periodically for centuries to the present day. Generally, lands are categorized as objects or goods, either owned by the state or society, or which can or cannot be owned at all. Each of these tenure provisions is based on the legal philosophy prevailing in a country. ${ }^{1}$ The State has main liability and duty towards the community to protect the entire nation of Indonesia and to advance public welfare as confirmed by the Preamble of the 1945 Constitution of the Republic of Indonesia (hereinafter abbreviated as 'the 1945 Constitution'). The Indonesia homelands are aimed at realizing the goal of the country to advance public welfare, educate the life of nation and participate in implementing world order.

The essence of land control can be seen from the provisions of Article 33 paragraph (3) of the 1945 Constitution that land as natural wealth under State power and it is used for the prosperity of the people. State control over land gives the authority for the State to arrange land ownership as manifested in Act No. 5 of 1960 the basic rule of agrarian and it is known as the Basic Agrarian Law. Basically, the establishment of the Basic Agrarian Law as an effort to eliminate dualism in the land registration system so that a simple land registration system can be given and guarantee legal certainty for all Indonesian people.

A requirement in the land registration process is the applicant for land rights must submit a number of documents as foundation of requested land ownership. These documents become a State archive maintained by the State Land Agency of the Republic of Indonesia in a form called vital archive (commonly known as 'warkah' in Indonesia). The role of vital archive is very important especially when there is a dispute over the registered land rights. In a trial process, vital archive becomes one of the evidences that are highly considered by the panel of judges. The National Land Agency is obliged to maintain vital archive and whenever it can be shown if requested by the judge who examining a land case.

Vital archive is a basic document of land ownership which as archive of land registration. In the land registration system, documents that used as vital archive are original documents which if not maintained will cause loss of ownership evidence from the applicant for title registration and freehold over land, so that vital archive will play a very important role in the judicial process. Considering vital archive is evidence that is always considered by the judges.

However, in the legislation and the rules and regulations of the head of the National Land Agency shows there is no a provision that regulates the liability of the National Land Agency for loss of vital archive which causes less protection of holders of land rights especially in the court, both civil, state and criminal administration. Therefore, the researcher is encouraged to do a research of those matters, namely how the role of vital archive of land right registration in realizing legal certainty for holders of land rights and how the form of liability of the National Land Agency for loss of vital archive of land rights registration.

\footnotetext{
${ }^{1}$ Agustina, E. (2018). The Social Function of Land Rights in Indonesia: The Basic Agrarian Law and Customary Rights by the State. Journal of Legal, Ethical and Regulatory Issues, 21(SI): 1-8.
} 


\section{Method of the Research}

The research was a socio-legal research using a descriptive method. To analyze the data, the researcher processes and analyzes qualitatively. It was done by using a theoretical foundation as analysis key in explaining the phenomena and it becomes a focus of research.

\section{Vital Archive for Right Issuance and Legal Certainty over the Rights of Certificate Holder}

Essentially, the objective and land registration system are stipulated in the Basic Agrarian Law, states that land registration is performed in order to provide legal certainty in agrarian sector. Vital archive is a document and material and juridical evidences for a plot of land that used as a basis for land registration. It shows that the document as basis for the issuance of the land rights certificate then becomes a document that must be maintained by the Land Office. This document is called vital archive (warkah). The term "warkah for land registration" or commonly referred to as only "warkah" within the National Land Agency is a set of documents used as the basis for the issuance of land certificate.

Vital archive for land registration is a type of document with unlimited period and it can also be referred to as a "living file" as long as the certified land still exists, it remains valid. It because if anytime arise problem that relate to a plot of land that have been certified, then vital archive plays an important role in determining who is right from the problem. Hence, from vital archive will be known whether the process of filing the certificate is in accordance with existing rules or not, as seen from the procedure and the truth of the data provided. ${ }^{1}$ Several things that can be proven through vital archive as follows:

a) Proof of fulfilling the principle of contradictory delimitatie is known from the document of measurement data (drawings) and the signatures of boundary neighbors

b) Proof of the correctness of the land site and size can be known from the map of the plot of land.

c) Proof of continuous control can be known from vital archive in the form of a statement letter of the physical land ownership and it is known by the local government.

d) Proof of good faith in the acquisition of land that can be known from the transitional evidence used as a vital archive such as a deed of sale and purchase, deed of grants and others.

e) Proof of fulfilling the principle of publication that can be known from the document in the form of an official report.

f) Proof of application of prudence in land registration that can be known from the minutes of land inspection.

All documents recorded in a vital archive for land registration have the validity of proof which shows that it is an important document in providing legal certainty to holders of land rights whose names are listed in the Certificate of Land Rights.

An assessment of the suitability of the issuance of a certificate with a statutory regulation must be assessed from vital archive, because in the evidentiary system in court, the validity of the proof lies in the original document, so even though the certificate holder has a photocopy, but the validity of the proof lies on vital archive. In the original document the land registration is stored, so without vital archive the evidence will be weak unless the other party acknowledges it. Thus, vital archive in the original land registration document and the certificate is only a derivative so that if the National Land Agency is unable to show vital archive in the examination process before a judge, then the legal force of the certificate will be weak.

The important role of vital archive for land registration was stated by Jaap Zevenbergen ${ }^{2}$ that that in many situations especially in developing countries, the objectives of project management were greatly simplified so as to cause many errors and decisions requiring a form of rapid improvement so that the land registration system had to be made in such a way as to be able to keep all the data is still maintained to facilitate the necessary improvements.

As view above that the role of vital archive becomes a reference if necessary correction for the future. It can be seen in the issuance of substitute certificates, restoring boundary, and land acquisition. Jean G. Manirakiza, ${ }^{3}$ stated that in solving land problems and disputes, all recorded land registration data is evidence that connects landowners with their land. This description shows that vital archive is a record of land registration data through which the legal relationship between the landowners and their land can be known.

Based on the legal construction, it indicates that in outline vital archive has a role as: Firstly, vital archive is a data record of land registration that connects the landowner with their land; Secondly, vital archive is an evidence for the correctness of the certificate issuance procedure; Thirdly, vital archive is an evidence for the

\footnotetext{
${ }^{1}$ Zafar, S. (2010). Pengamanan Warkah Dokumen Pendaftaran Tanah Melalui Digitalisasi Dokumen. Program Studi Manajemen dan Bisnis, ITB : Bogor

${ }^{2}$ Zevenbergen, J. "Systems of Land Registration Aspects and Effects", NCG Nederlandse Commissie voor Geodesie Netherlands Geodetic Commission Delft, September 2002

${ }^{3}$ Manirakiza, J.G. (2014). The Role of Land Record in Support of Post Conflict Land Administration : A case Study of Rwanda in Gasabo District, Faculty of Geo Information Science and earth Observation of The University of Twente.
} 
land right ownership by the right holder; Fourthly, vital archive is a reference document for corrections conducted in the future; and last but not least, vital archive is a dispute resolution document.

\section{Liability of the National Land Agency for the Loss of Vital Archive of Land Right Registration}

The National Land Agency is an agency that given an authority in the arrangement and administration of land in Indonesia. According to H.D. Stoud, the authority is Bevoegheid wet kan worden omscrevenals het geheel van bestuurechttelijke bevoegdheden door publiekrechtelijke rechtssubjecten in het bestuurechttelijke rechtsverkeer (authority can be explained as a whole of rules relating to the acquisition and use of government authority by public law subjects in public law). ${ }^{1}$ As such definition, it can be concluded that authority has a different understanding from competence.

Authority is a formal power that comes from the law, while authority is a specification of authority, it means that whoever (legal subject) is given authority by law then they are authorized to do something within that authority. From this authority the liability arises and causes accountability. ${ }^{2}$ Therefore, in this sense the essence of liability is a balance between an authority and the right when the government apparatus run their authority and violates the rules so that it results in the neglect of the interests and rights of the community. Spiro ${ }^{3}$ tried not to make a definition of liability but instead laid down a number of prerequisites for the emergence of liability including responsibility as accountability, responsibility as cause, and responsibility as obligation. Of these three things, the liability of the National Land Agency for vital archive and the loss of vital archive for land registration can be seen in several forms, namely administrative, civil and criminal.

\subsection{Administrative Liabilities}

The National Land Agency, especially the Land Office is an agency that has authority in land administration. Administrative discipline is one of the principles in conducting the duties, functions and authorities of the National Land Agency. Deviation and maintenance of land registration data is a duty that has been regulated both in PP No. 24 of 1997 and in KBPN No. 3 of 1997 so that implement or do not implement those duties will arouse liability of the Land Office both to the State and to the affected community.

The filing and maintenance of vital archive is an important part of the effort to establish an orderly administration of land affairs. In relation with the mechanism of filing and maintenance of vital archive in the Land Office, the researcher examined several important things to be criticized:

The First, the person responsible for the filing and maintenance of the vital archive is the Subsection Head of Right Registration of Land Office. In this case, the researcher sees the possibility of difficulties in supervising the maintenance and filing of vital archive, considers the main duties and functions of the Subsection Head of Right Registration is not only maintaining vital archive. Very high volume of work can lead to a lack of time for the subsection to supervise vital archive. For this condition, the researcher looks closely at the urgency of determining the person responsible for vital archive not in the position of structural officials who are burdened with other basic tasks. The person responsible for vital archive should a functional official who has archival expertise and his/her job is only to file/store, maintain and supervise the use of vital archive.

The Second, there lack of employees in vital archive room. The high volume of registration and transfer of rights at the Land Office will make it difficult to reorganize the right registration vital archive because every day employees are more busied with searching for vital archive for both transitional and dispute resolution purposes. Ideally, every vital archive in each subdistrict is managed by a minimum of 2 (two) person. In addition, the placement of employees with the status of partners (honorary) is very vulnerable considering that the documents in vital archive room are State documents, so all the officer should be civil servants with archival education basis.

The Third, storing and searching data manually in vital archive room of the Land Office is very difficult to search and maintain data. Ideally, information technology can be used in the maintenance of vital archive so that in and out of vital archive can be controlled quickly and accurately.

The Fourth, limited funding. Human resources and the mechanism of maintaining and storing of vital archive and the mechanism of controlling in the Land Office are one of the causes of the loss of vital archive for land right registration. Lending vital archive by other sections in need must be accompanied by documents as a basis for lend, for example, a lawsuit from the plaintiff, if vital archive is lent for the purpose of a court examination, a request document for rights if vital archive is lent for the purpose of transferring land rights. The lending party put a signature in the lending book and the signature of officer will be affixed when vital archive has been returned.

The Fifth, up to now there is no mechanism or procedure for the replacement of vital archive in the National Land Agency. Arrangements are only for land titles and lost certificates, while lost vital archive have not been

\footnotetext{
${ }^{1}$ Stout H.D, as cited in Fachruddin, I. (2004). Pengawasan Peradilan Administrasi Terhadap Tindakan Pemerintah, Bandung: Alumni. p. 4

${ }^{2}$ Mahmudi. (2007). Manajemen Kinerja Sektor Publik. Yogyakarta: Insan Media Bhakti, p. 102

${ }^{3}$ Liddle, R.W. (ed). (2001). Crafting Indonesian Democracy. Bandung: Mizan Media Utama, p. 110.
} 
regulated at all. In this regard, the researcher observes that not regulating the mechanism for the replacement of lost vital archive can be a problem for rights holders because the original documents are in vital archive. However, according to the researcher, the obligation to replace lost vital archive must basically be done under Act No. 43 of 2009 on Archives.

The Sixth, administrative liability for the maintenance of data can also be done by taking preventive measures, namely by making copies of vital archive sent to the Regional Office of the National Land Agency and one copy sent to the National Land Agency of the Republic of Indonesia and this will be easier if done back up data digitally in an information system.

As results of this research, as a repressive effort, an administrative sanction system is needed for the officers of vital archive to increase discipline in protecting the vital archive. The basis for applying administrative sanctions, although not yet regulated in agrarian regulations, can be found essentially in Act No. 43 of 2009 concerning Archives. The storage or filing of vital archive as the liability of the National Land Agency has administrative consequences both in preventing and overcoming it.

In fact, the implementation of the duties of the National Land Agency, in the event of a case, if vital archive is not found, an official report will be issued, known as the Official Report on the lost vital archive. However, the official reports were not followed up with efforts to make a vital archive for rights holders for example through the issuance of substitute vital archive. However, to be able to issue a substitute vital archive, there must be a source or reference. For this reason, it is important to digitize the right registration document so that it can become a reference for issuing a substitute vital archive.

Actually, the use of document digitalization of rights registration is not implemented by all Land Offices mainly due to limited funds and human resources. This is not only happening in Indonesia. O.P. Dubey ${ }^{1}$ stated that the government is responsible for improving the information centers in the form of the latest hardware, software, terminals and printers to speed up land data entry work. But the reality in India shows that progress throughout the country is very not balance. Some regions are able to make good progress, while others lag behind. As a result, land administration management is uneven.

Efforts to realize the digitalization of land data have been implemented in other countries, namely Nepal, as stated by Hira G. Maharjan ${ }^{2}$ that initially in Nepal; land administration services were provided using traditional methods and processes. The recording system is mainly based on a manual system. However, the increasing need for efficient and effective land administration services has led the Nepalese government to use Information and Communication Technology to improve efficiency and effectiveness in service delivery. This can bring improvements in efficiency, easy availability and accessibility of services and information to citizens, business organizations, professional users and government organizations.

\subsection{Civil Liabilities}

In civil law, the principle of liability is generally based on the element of error (fault liability or liability based on fault). This principle states that a person can only be held liable if there is an element of wrongdoing. Article 1365 of the Civil Code, commonly known as an article about acts against the law, requires the fulfillment of 4 (four) main elements, namely:

1) Presence of commit;

2) Presence of fault element;

3) Presence of loss suffered; and

4) Presence of a causal relationship between fault and loss.

In relation with this provision, the loss of vital archive for land rights registration can lead to lawsuits from parties who feel disadvantaged. However, up to now there has never been a civil claim, especially the illegal act submitted for the loss of vital archive at the Land Office.

As an institution/agency, the National Land Agency is a single entity so that civil liability can be given institutionally. This is different from criminal liability where liabilities are more focused on the personal. Officials or employees may move at any time but the liability for a civil fault will remain attached to the institution. Whoever the officer is in vital archive room and at when vital archive is lost, the National Land Agency must be institutionally ready to give its liabilities to the disadvantaged party.

\subsection{Criminal Liabilities}

Determining of which actions are considered as criminal acts, adhered to the principle called the principle of legality, a principle that determines that each criminal act must be determined as such by a rule of law. In relation with the loss of vital archive for right registration, up to now the laws and regulations in the field of land

\footnotetext{
${ }^{1}$ Dubey, O.P. (2012). Information Technology for Maintaining Land Records in India: An Operations Perspective, The IUP Journal of Operations Management, 11 (1): 50-57.

${ }^{2}$ Maharjan, H.G. (2015). Land Records Information Management System. Nepalese Journal on Geoinformatics, 14: $26-31$.
} 
have not provided firmness in its regulation. However, criminal liability for the loss of vital archive for right registration can be based on Act No. 43 of 2009 concerning Archives. Vital archive in the view of researchers is an active archive because it is used continuously without a period of time.

According to the researcher, criminal liability on vital archive as a State archive can be seen from the provisions in Act No. 43 of 2009, as follows:

1) Article 81

Everyone who intentionally controls and/or owns the State archives as referred to in Article 33 for his/her own interests or other people who are not entitled to be sentenced to a maximum imprisonment of 5 (five) years or a maximum fine of Rp. 250.000.000.

2) Article 82

Everyone who intentionally provides a dynamic archive to unauthorized archive users as referred to in Article 42 paragraph (1) shall be liable to a maximum imprisonment of 3 (three) years or a maximum fine of Rp. 125.000.000.

3) Article 83

Everyone who intentionally does not maintain the integrity, security and safety of State archives that are maintained for the interests of the State as referred to in Article 42 paragraph (3) shall be sentenced to a maximum imprisonment of 1 (one) year or a maximum fine of Rp. 25.000.000.

4) Article 84

Officials who intentionally do not file and report as referred to in Article 43 paragraph (1) shall be sentenced to a maximum imprisonment of 10 (ten) years and a maximum fine of Rp.500.000.000.

5) Article 85

Everyone who intentionally does not maintain the confidentiality of closed records as referred to in Article 44 paragraph (2) shall be liable to a maximum imprisonment of 5 (five) years or a maximum fine of Rp. 250.000.000.

6) Article 86

Everyone who intentionally destroys records (archives) outside the proper procedure as referred to in Article 51 paragraph (2) shall be liable to a maximum imprisonment of 10 (ten) years and a maximum fine of Rp.500.000.000.

7) Article 87

Everyone who trades or submits an archive that has a historical use value to another party outside of what has been determined as referred to in Article 53 shall be liable to a maximum imprisonment of 10 (ten) years and a maximum fine of Rp.500.000.000.

8) Article 88

Third parties who fail to submit archives created from activities funded by the State budget as referred to in Article 58 paragraph (3) shall be liable to a maximum imprisonment of 5 (five) years or a maximum fine of Rp. 250.000.000.

From 8 (eight) provisions as mentioned above, the researcher observes that criminal liability for the loss of vital archive for land registration can be based on the provisions of Article 83 of Act No. 43 of 2009. Criminal liability is attached to the person so that if vital archive is declared lost then the person who lost it can provide criminal liability. The difficulty faced is to determine who and when vital archive is lost. If vital archive is often used for example for the transfer or encumbrance of mortgages, it is easier to know when vital archive is lost by looking at the records of data changes in the certificate of the right holder. However, if the transfer never occurs, it is difficult to detect the time of the loss of vital archive.

Basically, difficulties in determining the liable parties for the loss of vital archive can be prevented by an intense monitoring system and periodic reporting of vital archive in the Land Office. Likewise, the transfer of employees should be accompanied by an Official Report on vital archive which is preceded by checking by employees who are not involved in the data maintenance process.

\section{Conclusion}

Vital archive for land registration has a very important role in the legal certainty of land rights. It is a data record of land registration that connects the land owner with his/her land. In addition, vital archive is an evidence of the truth of the procedure for the issuance of land certificates as well as an evidence of the correctness of land ownership by right holders. The form of liabilities of the National Land Agency for the loss of vital archive for land registration is administrative, civil and criminal liabilities. But unfortunately, this has not been regulated in the legislation in the agrarian sector. Until now, the application of these liabilities can be done based on the archive's laws.

As a form of liability of the National Land Agency administratively, it is necessary to digitize the land registration records so that if vital archive is lost then the replacement can be done by referring to the digital record. To be able to increase the sense of liabilities towards the maintenance of vital archive, the socialization 
of archive laws needs to be done comprehensively to provide clarity related to the mechanism of liability in the agrarian sector.

\section{References}

Agustina, E. (2018). The Social Function of Land Rights in Indonesia: The Basic Agrarian Law and Customary Rights by the State. Journal of Legal, Ethical and Regulatory Issues, 21(SI): 1-8.

Dubey, O.P. (2012). Information Technology for Maintaining Land Records in India: An Operations Perspective, The IUP Journal of Operations Management, 11 (1): 50-57.

Fachruddin, I. (2004). Pengawasan Peradilan Administrasi Terhadap Tindakan Pemerintah, Bandung: Alumni.

Liddle, R.W. (ed). (2001). Crafting Indonesian Democracy. Bandung: Mizan Media Utama.

Maharjan, H.G. (2015). Land Records Information Management System. Nepalese Journal on Geoinformatics, 14: $26-31$.

Mahmudi. (2007). Manajemen Kinerja Sektor Publik. Yogyakarta: Insan Media Bhakti.

Manirakiza, J.G. (2014). The Role of Land Record in Support of Post Conflict Land Administration : A case Study of Rwanda in Gasabo District, Faculty of Geo Information Science and earth Observation of The University of Twente.

Zafar, S. (2010). Pengamanan Warkah Dokumen Pendaftaran Tanah Melalui Digitalisasi Dokumen. Program Studi Manajemen dan Bisnis, ITB : Bogor.

Zevenbergen, J. "Systems of Land Registration Aspects and Effects", NCG Nederlandse Commissie voor Geodesie Netherlands Geodetic Commission Delft, September 2002. 